\title{
Regulation of Amygdala-Dependent Learning by Brain-Derived Neurotrophic Factor is Mediated by Extracellular Signal-Regulated Kinase and Phosphatidylinositol-3-Kinase
}

\author{
Li-Chin Ou' and Po-Wu Gean*,' \\ 'Institute of Basic Medical Sciences and Department of Pharmacology, National Cheng-Kung University, Tainan, Taiwan, ROC
}

\begin{abstract}
This study is designed to characterize the signal cascades by which brain-derived neurotrophic factor (BDNF) modulates long-term memory of fear conditioning. Enzyme-linked immunosorbent assay (ELISA) and Western blot analysis of tissue homogenates taken from fear-conditioned rats showed an increase in the amygdala of BDNF protein levels and its receptor TrkB phosphorylation. Bilateral administration of a TrkB ligand scavenger TrkB lgG and a Trk-specific tyrosine kinase inhibitor K252a to the amygdala impaired fear memory, as measured with fear-potentiated startle. Fear conditioning resulted in the association of Shc and TrkB, Shc and Ras, the increase in active Ras and phosphorylation of mitogen-activated protein kinase (MAPK). Treatment of amygdala slices with BDNF for 15 min increased the levels of active Ras, and MAPK and Akt phosphorylation. BDNF-induced MAPK phosphorylation was completely abolished by MEK inhibitors, and was partially inhibited by farnesyltransferase or phosphatidylinositol-3 kinase (PI-3 kinase) inhibitors. On the other hand, BDNF-induced Akt phosphorylation was unaffected by farnesyltransferase or MEK inhibitors, but could be blocked by $\mathrm{PI}-3$ kinase inhibitors. Together, these data suggest a requirement of BDNF for fear learning. The memory-enhancing effect of BDNF involves the activation of MAPK and PI-3 kinase. BDNF-induced MAPK phosphorylation in the amygdala is mediated via TrkB and the Shc-binding site. Shc binding to TrkB leads to activation of Ras, Raf, and MEK. In addition, BDNF could induce phosphorylation of MAPK via activation of $\mathrm{Pl}-3$ kinase.
\end{abstract}

Neuropsychopharmacology (2006) 3 I, 287-296. doi:I0. I038/s.npp. I 300830; published online 20 July 2005

Keywords: neurotrophin; BNDF; long-term potentiation; learning and memory; amygdala; fear conditioning

\section{INTRODUCTION}

Brain-derived neurotrophic factor (BDNF) is a growth factor involved in long-term structural and functional changes (Poo, 2001; Zhang and Poo, 2002) underlying neuronal development and survival (McAllister et al, 1995; Hetman et al, 1999), drug-seeking behavior (Grimm et al, 2003; Lu et al, 2004), and synaptic plasticity such as longterm potentiation (LTP) (Korte et al, 1995; Patterson et al, 1996; Schuman, 1999; Pang et al, 2004) and learning and memory (Yamada et al, 2002; Tyler et al, 2002; Mizuno et al, 2003). For example, BDNF mRNA increased in the hippocampus after contextual learning (Hall et al, 2000) and radial maze training (Mizuno et al, 2000), in the cortical

\footnotetext{
*Correspondence: Dr P-W Gean, Institute of Basic Medical Sciences and Department of Pharmacology, National Cheng-Kung University, No. I Ta-Shieh Rd., Tainan 70I0I, Taiwan, ROC, Tel: +886 6 2353535, Fax: + 8866 2749296, E-mail: powu@mail.ncku.edu.tw Received 20 January 2005; revised 9 June 2005; accepted 10 June 2005 Online publication: 20 June 2005 at http://www.acnp.org/citations/ Npp062005050048/default.pdf
}

and limbic regions following formation of a declarative or a social recognition memory (Tokuyama et al, 2000). Bath perfusion of BDNF onto hippocampal slices (Kang and Schuman, 1995; Messaoudi et al, 2002) or intrahippocampal infusion of BDNF in whole animals (Ying et al, 2002) evoked long-lasting enhancement of synaptic efficacy. Conversely, interfering with BDNF action by caged antibody, antisense, or knockout technology has deleterious effects on memory formation and LTP (Korte et al, 1995; Ma et al, 1998; Lee et al, 2004). Furthermore, depletion of extracellular BDNF by using scavenger protein TrkB-IgG revealed that BDNF secretion occurred under conditions that induced LTP in hippocampal slices (Figurov et al, 1996; Kang et al, 1997; Chen et al, 1999), suggesting a causal link between neurotrophin secretion and activity-dependent synaptic plasticity.

Despite the well-known functions of BDNF in the hippocampus, relatively little information is available regarding the role of BDNF in the amygdala. Only in a recent report, in which fear conditioning resulted in an increase in BDNF mRNA levels and expression of a 
dominant-negative TrkB receptor in the amygdala impaired acquisition of fear learning, had a role played by BDNF in amygdala-dependent synaptic plasticity been suggested (Rattiner et al, 2004). We and other laboratories have previously shown that activation of phosphatidylinositol-3 kinase (PI-3 kinase) and mitogen-activated protein kinase (MAPK) is required for acquisition of a conditioned fear (Schafe et al, 2000; Lin et al, 2001). BDNF binding to TrkB receptor leads to activation of Ras/MAPK and PI-3 kinase/ Akt pathways. Since these signal cascades have a welldescribed association to BDNF action in other systems, in the present study, we aim to investigate the role of BDNF in the acquisition of fear memory.

\section{MATERIALS AND METHODS}

\section{Surgery}

Sprague-Dawley rats (4-6-week old) were anesthetized with sodium pentobarbital (50-mg/kg, i.p.), and, subsequently, were mounted on a stereotaxic apparatus. Two cannula made of 22-gauge stainless steel tubing (C313G, Plastic Products, Roanoke, VA) were implanted bilaterally into the lateral (LA) or basolateral (BLA) amygdala (anteroposterior (AP), $-2.8 \mathrm{~mm}$; mediolateral (ML), $\pm 4.5 \mathrm{~mm}$; dorsoventral (DV), $-7.0 \mathrm{~mm}$ ) (Paxinos and Watson, 1986). A 28-gauge dummy cannula was inserted into each cannula to prevent clogging. Three jewelry screws were implanted over the skull, serving as anchors, and the whole assembly was affixed on the skull with dental cement. The rats were monitored and handled daily, and were given 7 days to recover. TrkB/Fc chimera (Sigma, St Louis, MO), LY294002, U0126, wortmannin, PD98059 (Tocris, UK), K252a (BIOMOL Research Biomolecules for Research), recombinant human BDNF (Chemicon International Inc., Temecula, CA), and FTI277 (Calbiochem Corp., La Jolla, CA) were administered bilaterally to the amygdala in a volume of $1-1.5 \mu \mathrm{l}$ at a rate of $0.1 \mu \mathrm{l} / \mathrm{min}$.

\section{Slice Preparation}

Male Sprague-Dawley 4- to 5-week-old rats were decapitated, and their brains were rapidly removed and placed in cold oxygenated artificial cerebrospinal fluid (ACSF) solution. Subsequently, the brain was hemisected and glued to the chuck of a Vibroslice tissue slicer. Transverse slices of $400 \mu \mathrm{m}$ thickness were cut, and the appropriate slices were placed in a beaker of oxygenated ACSF at room temperature for at least $1 \mathrm{~h}$ before the drug incubation experiment. ACSF solution had the following composition (in $\mathrm{mM}$ ): $\mathrm{NaCl} 117$, $\mathrm{KCl}$ 4.7, $\mathrm{CaCl}_{2} 2.5, \mathrm{MgCl}_{2}$ 1.2, $\mathrm{NaHCO}_{3} 25, \mathrm{NaH}_{2} \mathrm{PO}_{4} 1.2$, and glucose 11 . The ACSF was bubbled continuously with $95 \%$ $\mathrm{O}_{2} / 5 \% \mathrm{CO}_{2}$ and had a $\mathrm{pH}$ of 7.4. Amygdala slices were incubated with BDNF $(100 \mathrm{ng} / \mathrm{ml})$ for $15 \mathrm{~min}$, and then BDNF was washed out and active Ras, p-MAPK, and p-AKT were determined. In the experiments of the effects of drug on BDNF-induced MAPK and Akt phosphorylation, K252a $(300 \mathrm{nM})$, U0126 $(10 \mu \mathrm{M})$, PD98059 $(50 \mu \mathrm{M})$, LY294002 $(10 \mu \mathrm{M})$ or wortmannin $(100 \mathrm{nM})$ were added to the slices 30 min before and in the presence of BDNF, whereas FTI277 (2.5 $\mathrm{mM}$ in $50 \% \mathrm{DMSO}, 1.5 \mu \mathrm{l}$ per side) was infused into the amygdala $24 \mathrm{~h}$ before the preparation of slices.

\section{Fear Conditioning}

Rats were trained and tested in a stabilimeter device. A piezoelectric device mounted below the stabilimeter detects and transduces the motion of the cylinder produced by the whole body startle response of the rat (San Diego Instrument, San Diego). The whole setup was enclosed in a ventilated, sound-attenuating cabinet (length $38 \mathrm{~cm}$, width $38 \mathrm{~cm}$, and height $55 \mathrm{~cm}$ ). The acoustic startle stimulus was a $50 \mathrm{~ms}$ white noise at the intensity of $95 \mathrm{~dB}$. The visual CS was a $3.7 \mathrm{~s}$ light produced by an $8 \mathrm{~W}$ fluorescent bulb attached to the back of the stabilimeter. The US was a $0.6 \mathrm{~mA}$ footshock with a duration of $0.5 \mathrm{~s}$.

Acclimation. On three consecutive days, rats were placed in the startle test boxes for $10 \mathrm{~min}$ and returned to their home cages.

Matching. On two consecutive days, rats were placed in the startle box and, 3 min later, presented with 10 startle stimuli at 2 min intertrial interval (ITI). On the basis of their mean startle amplitudes in the second of these two sessions, rats were matched into groups with similar response levels.

Training. Rats were placed in the startle boxes and received 10 light-footshock pairings with an ITI of $2 \mathrm{~min}$. Unpaired controls received the same number of light and footshock presentation, but in a pseudorandom fashion in which the US could occur at any time except at the $3.2 \mathrm{~s}$. following the CS.

Test. At $24 \mathrm{~h}$ after training, rats were tested for fearpotentiated startle. This involved 10 startle-eliciting noise bursts presented alone (noise-alone trial) and 10 noise bursts presented $3.2 \mathrm{~s}$. after onset of the $3.7 \mathrm{~s}$ light (lightnoise trials). The two trial types were presented in a balanced mixed order (ITI, $30 \mathrm{~s}$ ). The percentage of fearpotentiated startle was computed as follows: ((startle amplitude on CS-noise minus noise-alone trials)/(noisealone trials) $) \times 100$.

\section{Western Blot Analysis}

Amygdala slices were prepared as described above. The LA and BLA subregions were dissected out under a microscope, and were frozen and stored at $-80^{\circ} \mathrm{C}$ until processed. The tissues were sonicated briefly in ice-cold buffer $(50 \mathrm{mM}$ Tris-HCl, pH 7.5, 0.3 M sucrose, $5 \mathrm{mM}$ EDTA, $2 \mathrm{mM}$ sodium pyrophosphate, $1 \mathrm{mM}$ sodium orthovanadate, $1 \mathrm{mM}$ phenylmethylsulfonyl fluoride (PMSF), $20 \mu \mathrm{g} / \mathrm{ml}$ leupeptin, $4 \mu \mathrm{g} / \mathrm{ml}$ aprotinin, and $1 \%$ Triton $\times 100)$. Following sonication, the samples were centrifuged at $14000 \mathrm{rpm}$ for $30 \mathrm{~min}$ and the supernatant was obtained. Protein concentration in the soluble fraction was then measured using a Bradford assay, with bovine serum albumin as the standard. Equivalent amounts of protein for each sample were resolved in $8.5 \%$ SDS-polyacrylamide gels, blotted electrophoretically to Immobilon, and blocked overnight in TBS buffer $(50 \mathrm{mM}$ Tris- $\mathrm{HCl}, \mathrm{pH} 7.5,150 \mathrm{mM} \mathrm{NaCl}$ ) containing $2 \%$ bovine serum albumin. For detection of the phosphorylated forms of Akt and MAPK, blots were incubated with anti-phospho-Akt (1:1000, Cell Signaling Technology Inc., 
Beverly, MA) and anti-phospho-MAPK (1:1000, Cell Signaling Tech.) antibodies. To control the content of the specific protein per lane, membranes were stripped with $100 \mathrm{mM} \beta$-mercaptoethanol and $2 \%$ SDS in $62.5 \mathrm{mM}$ Tris$\mathrm{HCl}, \mathrm{pH} 6.8$, for $30 \mathrm{~min}$ at $70^{\circ} \mathrm{C}$ and reprobed with rabbit anti-pan-MAPK (Cell Signaling Tech.) or rabbit anti-Akt (Cell Signaling Tech.) antibodies. An enhanced chemiluminescence kit (Amersham) was used for detection. Western blots were developed in the linear range used for densitometry. The density of the immunoblots was determined by an image analysis system installed with a software BIO-ID (Vilber Lourmat, France). Active trkB and kinase levels in paired and unpaired animals were expressed as a percentage of those in naïve controls.

\section{Immunoprecipitation}

Amygdala homogenate was prepared as described above. For phosphorylation analysis of $\operatorname{TrkB}, 250 \mu \mathrm{g}$ of amygdala homogenate was incubated with anti-phospho-Tyrosine antibody ( $15 \mu \mathrm{l}$, Santa Cruz Biotech.) in $400 \mu \mathrm{l}$ of ice-cold homogenization buffer without Triton X100 at $4{ }^{\circ} \mathrm{C}$ for $1 \mathrm{~h}$, and then with protein G-coupled Agarose beads $(15 \mu \mathrm{l}$, Sigma) at $4^{\circ} \mathrm{C}$ for $6 \mathrm{~h}$. The immunoprecipitate was separated in $8.5 \%$ SDS-PAGE, transferred to Immobilon, and probed with polyclonal antibodies specific to $\operatorname{TrkB}(1: 1000$, Santa Cruz Biotech.). For the protein-protein interaction experiment, amygdala extracts $(250 \mu \mathrm{g})$ were immunoprecipitated with anti-Shc antibody ( $15 \mu \mathrm{l}$, Santa Cruz Biotech.) The extracts and anti-Shc antibody were incubated at $4{ }^{\circ} \mathrm{C}$ for $1 \mathrm{~h}$. Protein G-coupled Agarose beads were added to the extracts, and the mixture was incubated at $4{ }^{\circ} \mathrm{C}$ overnight. The immunoprecipitated protein was detected with antiTrkB and anti-Pan-Ras antibodies.

\section{Ras Pull-Down Assay}

Ras activity was assessed using Ras Activation Assay Kit (Cytoskeleton Inc., Denver, CO). The assay used a glutathione S-transferase (GST)-fusion protein containing the Ras-binding domain (RBD) of Raf kinase. The Raf-RBD is in the form of a GST fusion protein which allows one to 'pull down' the Raf-RBD/GTP-Ras complex with glutathione affinity beads (de Rooij and Bos, 1997; Johan and Johannes, 1997). The LA and BLA subregions of the amygdala were sonicated briefly in ice-cold homogenization buffer and centrifuged at $8000 \mathrm{rpm}$ for $5 \mathrm{~min}$, and the supernatant was obtained. Each tissue extract $(100 \mu \mathrm{g})$ was added to $30 \mu \mathrm{g}$ of Raf-1 RBD protein agarose beads. The mixture was incubated for $1 \mathrm{~h}$ at $4{ }^{\circ} \mathrm{C}$ and the agarose beads were pelleted by centrifugation and washed. The immunoprecipitate was separated in $12 \%$ SDS-PAGE, transferred to Immobilon, and probed with anti-Pan-Ras antibody.

\section{BDNF Immunoassay}

BDNF protein was quantified using an enzyme-linked immunosorbent assay (ELISA) (ChemiKine ${ }^{\mathrm{TM}}$ BDNF Sandwich ELISA Kit, Chemicon International Inc., Temecula, CA) as per the manufacturer's protocol. Rabbit polyclonal antibody generated against human BDNF is coated onto a microplate to capture unknown BDNF concentrations from the LA and BLA homogenates. Samples $(200 \mu \mathrm{g})$ were added to triplicate wells in each plate, and serial dilutions of BDNF standard were added to duplicate wells in each plate in order to generate a standard curve. BDNF-specific, biotinconjugated, mouse monoclonal antibody $(1: 1000)$ detected the captured BDNF. After addition of streptavidin enzyme, substrate and stop solution, the amount of BDNF was determined. Unknown BDNF concentrations were compared with known BDNF concentrations using a calibration curve. The assay has a detection limit of $7.8 \mathrm{pg} / \mathrm{ml}$ and no crossreactivity with other related neurotrophic factors. The intra- and interassay coefficients of variations were 3.7 and $8.5 \%$ respectively. BDNF protein levels in paired and unpaired rats were expressed as a percentage of those in naïve controls.

\section{Data Analysis}

Data were analyzed with ANOVA. A single-factor ANOVA and post hoc comparisons were used to analyze the time courses of BDNF expression and TrkB phosphorylation after fear conditioning, and BDNF-induced MAPK and Akt phosphorylation in the amygdala slices. A two-way ANOVA was used to analyze differences of startle reflex among paired, unpaired, vehicle control, and inhibitor-treated groups. All values in the text and figure legends are mean \pm SEM.

\section{RESULTS}

\section{Role of Endogenous BDNF in Fear Conditioning}

After habituation to the experimental chambers, animals received 10 pairings of light and footshock. Subsequently, the levels of BDNF were quantified with the ELISA at several time points ranging from immediately $(0 \mathrm{~min})$ to $8 \mathrm{~h}$ after fear conditioning. Figure la shows that BDNF levels significantly increased at $30 \mathrm{~min}$ after training, peaked at $1 \mathrm{~h}$, and returned to control levels within $4 \mathrm{~h}\left(\mathrm{~F}_{(7,45)}=12.36\right.$, $p<0.0001$ ), when compared with unpaired controls. Post hoc comparison revealed the differences between control and $30 \mathrm{~min}(p<0.05), 1(p<0.001)$, and $2 \mathrm{~h}(p<0.05)$ time points. No significant difference was detected between unpaired control and other time points $(p>0.05)$. To determine if increase in BDNF was specific for the amygdala, additional experiments were performed to measure BDNF protein levels in the hippocampus and cortex. As illustrated in Figure 1a, acquisition of conditioned fear did not lead to an increase in BDNF at $0.5,1$, and $2 \mathrm{~h}$ after training in the hippocampus $\left(\mathrm{F}_{(3,14)}=1.14\right.$, $p=0.37)$ and cortex $\left(\mathrm{F}_{(3,14)}=0.12, p=0.95\right)$. These results indicate that regulation of BDNF occurs in regions of the brain involved in the formation of fear memory.

We next determined whether BDNF receptor TrkB was activated by measuring phosphorylation of $\operatorname{Trk} B$ in the LA and BLA. TrkB phosphorylation was quantified by immunoprecipitation with phosphotyrosine antibody followed by immunoblotting with TrkB antibody. Figure $1 \mathrm{~b}$ shows that $\mathrm{p}$-TrkB levels significantly increased at $30 \mathrm{~min}$ and reached a peak at $1 \mathrm{~h}$ after training $\left(\mathrm{F}_{(6,14)}=14.42\right.$, $p<0.001)$. 


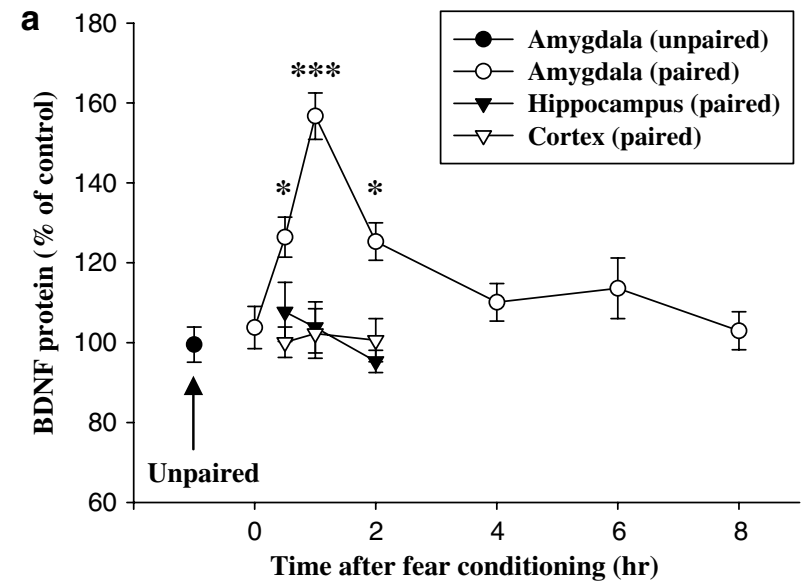

b
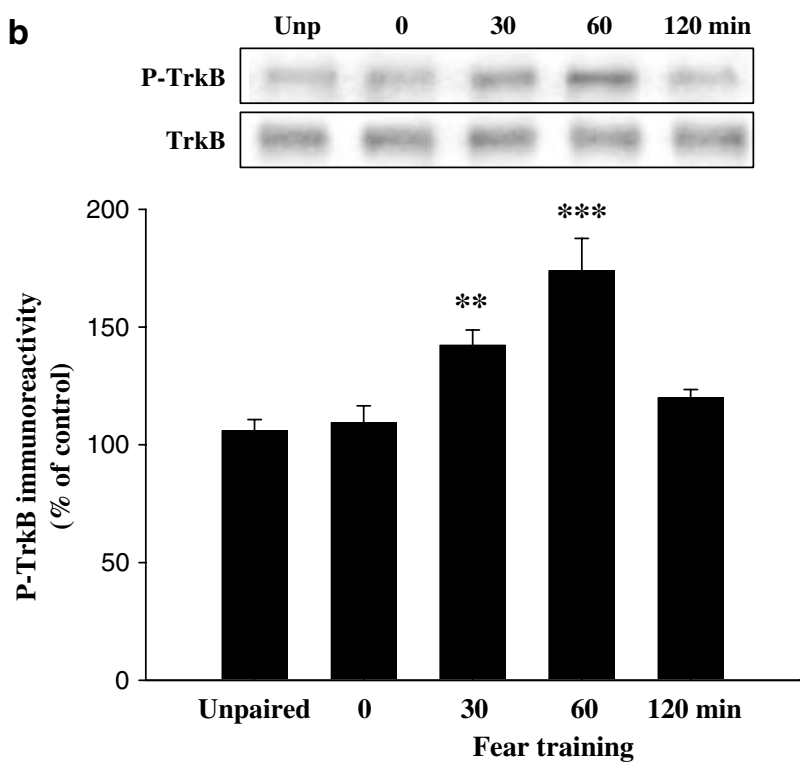

Figure I Fear conditioning results in the increases in BDNF protein and TrkB phosphorylation. (a) Temporal changes in BDNF protein levels at various time points after training. BDNF protein was detected and quantified using an ELISA assay. BDNF protein levels in paired and unpaired rats were expressed as a percentage of those in naïve controls. (b) At various periods after fear conditioning, tissue homogenates from the LA and BLA were immunoprecipitated with phosphotyrosine antibody followed by immunoblotting with TrkB antibody. P-TrkB phosphorylation levels in paired and unpaired rats were expressed as a percentage of those in naiive controls. All the unpaired animals were killed at I $\mathrm{h}$ after training. **** $p<0.00$ I, ** $p<0.0$ I, * $p<0.05$ vs unpaired control.

To investigate whether endogenous BDNF contributes to fear conditioning, we used a TrkB-specific 'receptor body' that contains the ligand-binding domain of $\operatorname{TrkB}$ receptor coupled to the Fc fragment of human immunoglobulin. The compound acts as a false receptor and scavenges unbound TrkB ligands (Shelton et al, 1995; Binder et al, 1999; Patterson et al, 2001). TrkB IgG (1.3 $\mu \mathrm{g}$ in $1 \mu \mathrm{l}$ PBS solution, $1.5 \mu \mathrm{l}$ per side) was microinjected bilaterally into the amygdala $30 \mathrm{~min}$ before training. Figure $2 \mathrm{a}$ shows that TrkB IgG impaired fear memory. Fear training elicited a startle potentiation of $174.1 \pm 12.5 \%(n=12)$. The magnitude of startle potentiation was reduced to $38.6 \pm 3.2 \%$

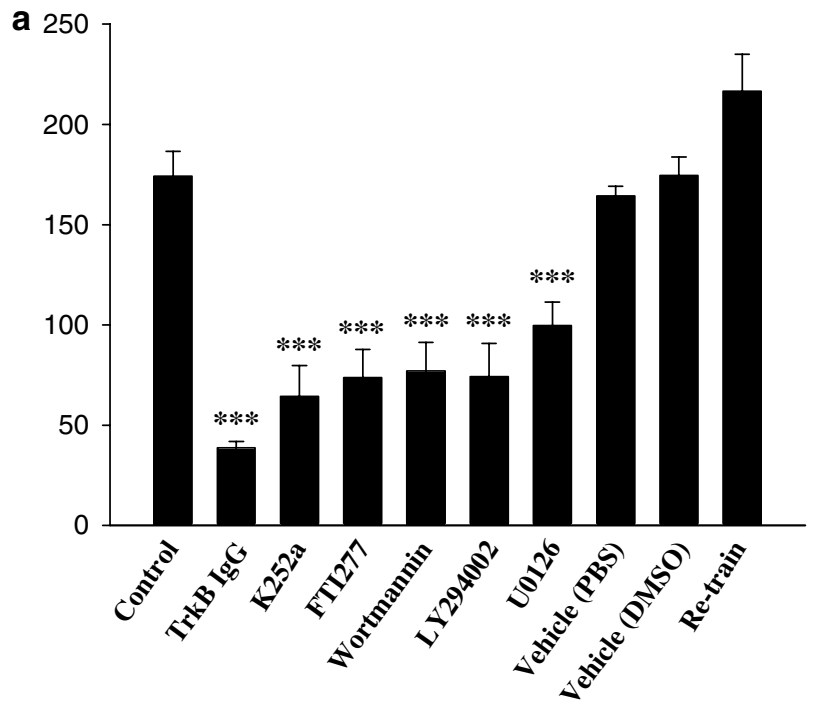

b
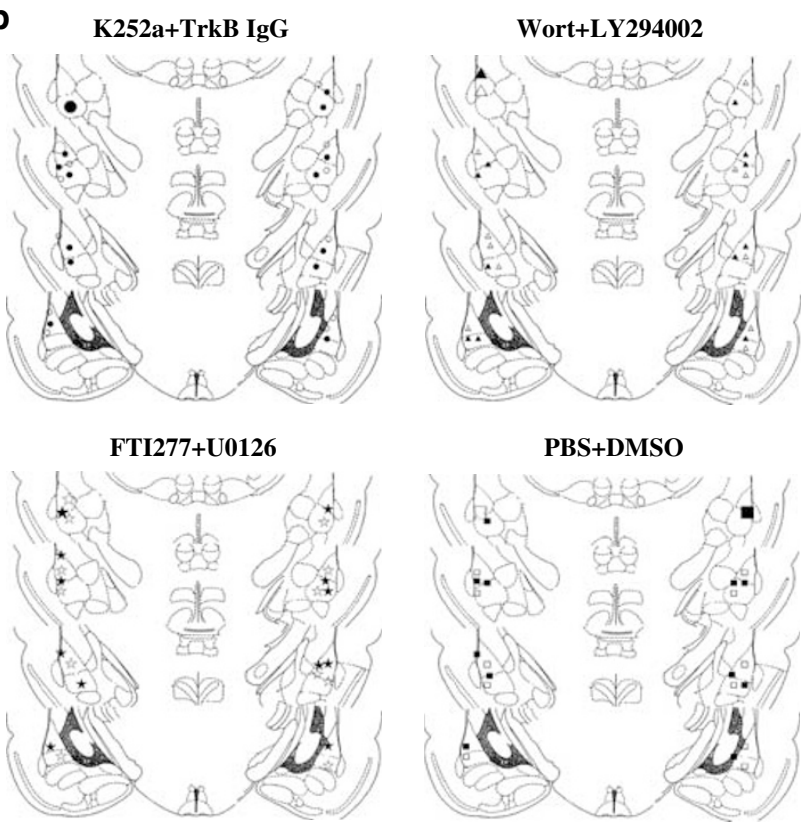

Figure 2 Effects of intra-amygdala administration of drugs on fearpotentiated startle. (a) Rats were given 10 pairings of light and footshock and $\mathrm{K} 252 \mathrm{a}(35.7 \mu \mathrm{M}$ in 50\% DMSO, I.5 $\mu$ per side), TrkB IgG $(\mathrm{I} .3 \mu \mathrm{g}$ in I $\mu \mathrm{l}$ PBS solution, I. $5 \mu \mathrm{l}$ per side), wortmannin $(5 \mu \mathrm{g} / \mu \mathrm{l}$ in $50 \% \mathrm{DMSO}, \mathrm{I} \mu \mathrm{l}$ per side), LY294002 (30 $\mu \mathrm{g} / \mu \mathrm{l}$ in 50\% DMSO, I $\mu \mathrm{l}$ per side), or $\cup 0 \mathrm{I} 26$ ( | $\mu \mathrm{g} / \mu \mathrm{|}$ in $50 \%$ DMSO, I $\mu$ l per side) were microinjected bilaterally into the LA or BLA 30 min before training, whereas FTI277 $(2.5 \mathrm{mM}$ in 50\% DMSO, I.5 $\mu \mathrm{l}$ per side) was given $24 \mathrm{~h}$ before training. Memory retention was tested $24 \mathrm{~h}$ after training. At 5 days after test, TrkB IgG-treated rats were re-trained and startle reflex was significantly increased to level comparable with control animals. $* * * * 00.001, * * p<0.01$ vs control. (b) Cannula tip placements

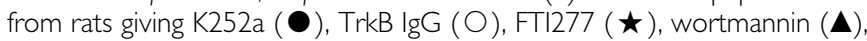
LY294002 $(\Delta)$, UOI26 ( $\downarrow)$, vehicle-PBS $(\boldsymbol{\square})$, and vehicle-DMSO $(\square)$ in experiments (a).

( $n=6, p<0.001)$ in TrkB IgG-treated rats. Similarly, rats that received a Trk-selective tyrosine kinase inhibitor K252a (35.7 $\mu \mathrm{M}$ in 50\% DMSO, $1.5 \mu \mathrm{l}$ per side) exhibited less startle reflex $(64.4 \pm 15.3 \%$ of potentiation, $n=7, p<0.001)$. As a control, rats were given vehicle, PBS (startle amplitude 
$164.3 \pm 4.9 \%, n=6)$, or DMSO $(50 \%, 174.6 \pm 9.1 \%, n=6)$ alone; both vehicles did not affect startle amplitude. Cannula tip placements in these experiments are shown in Figure 2b.

To rule out the possibility of TrkB IgG-induced damage to the amygdala, 5 days after test, TrkB IgG-treated rats were re-trained. Figure $2 \mathrm{a}$ shows that startle reflex in these rats increased to levels comparable with control animals.

We also examined whether pretesting injection of TrkB IgG affected fear memory. We found that there was no difference in the startle amplitude between TrkB IgG $(184.0 \pm 10.9, n=6)$ and vehicle $(178.7 \pm 11.5, n=6)$ groups $\left(t_{(10)}=0.28, p=0.78\right)$. The failure of $\operatorname{TrkB}$ IgG to influence expression of fear memory ruled out the potential nonspecific effects of this compound on sensory processing at the time of training.

\section{Exogenous BDNF Increases the Magnitude of Fear-Potentiated Startle}

We examined whether BDNF affected $0.2 \mu \mathrm{g} / \mu \mathrm{l}$ fearpotentiated startle by bilateral injection of BDNF $(9.2 \mathrm{mg} /$ $\mathrm{ml}, 1.5 \mu \mathrm{l}$ per side) into the amygdala $30 \mathrm{~min}$ before training. Retention of memory was assessed $24 \mathrm{~h}$ later. As illustrated in Figure 3a, startle amplitude in BDNF-treated rats $(267.2 \pm 17.2 \%, n=12)$ was significantly higher than those of conditioned control rats $\left(t_{(22)}=4.45, p<0.001\right)$. To confirm whether the enhancement of fear-potentiated startle by BDNF was mediated by activation of $\operatorname{TrkB}$, we administered TrkB IgG $(1.3 \mu \mathrm{g}$ in $1 \mu \mathrm{l}$ PBS solution, $1.5 \mu \mathrm{l}$ per side) $20-25 \mathrm{~min}$ before BDNF into the amygdala. Quantification of startle potentiation $24 \mathrm{~h}$ after training revealed that TrkB IgG not only blocked the action of BDNF $\left(t_{(16)}=8.60, p<0.001\right)$ but also reduced the startle amplitude to below the control level $(44.7 \pm 11.5 \%, n=6)$, such that there was no difference in the amount of startle amplitude between TrkB IgG and BDNF/TrkB IgG rats $\left(t_{(10)}=0.52, p=0.62\right)$. In comparison, rats that received BDNF and vehicle exhibited a normal potentiation $(244.7 \pm 13.4 \%, n=6)$. Similarly, K252a $(35.7 \mu \mathrm{M}$ in $50 \%$ DMSO, $1.5 \mu \mathrm{l}$ per side) not only blocked the action of $\operatorname{BDNF}\left(t_{(16)}=7.34, p<0.001\right)$ but also reduced the startle amplitude to below the control level $(71.3 \pm 11.5 \%, n=6)$. Cannula tip placements in these experiments are shown in Figure 3b.

\section{Intracellular Mechanisms for BDNF Enhancement of Fear Memory}

Intracellular signaling of activated $\operatorname{TrkB}$ is mediated by recruitment of adaptor proteins such as Shc, which subsequently interacts with Grb2. Grb2, in turn, binds to Ras guanine nucleotide exchange factor, SOS. Shc/Grb2/SOS complex gets localized to the membrane through the interaction of Shc with phosphorylated receptor, and mediates signaling to the Ras-MAPK pathway (Kaplan and Miller, 2000; Ravichandran, 2001). We investigated the interaction between Shc and TrkB receptor with coimmunoprecipitation (co-IP). Since Shc (H-108) detects p66, p52, p46 and N-Shc, we used Shc (H-108) antibody for immunoprecipitation and $\mathrm{N}$-Shc for immunoblotting. In the first set of experiments, protein extracts from LA and
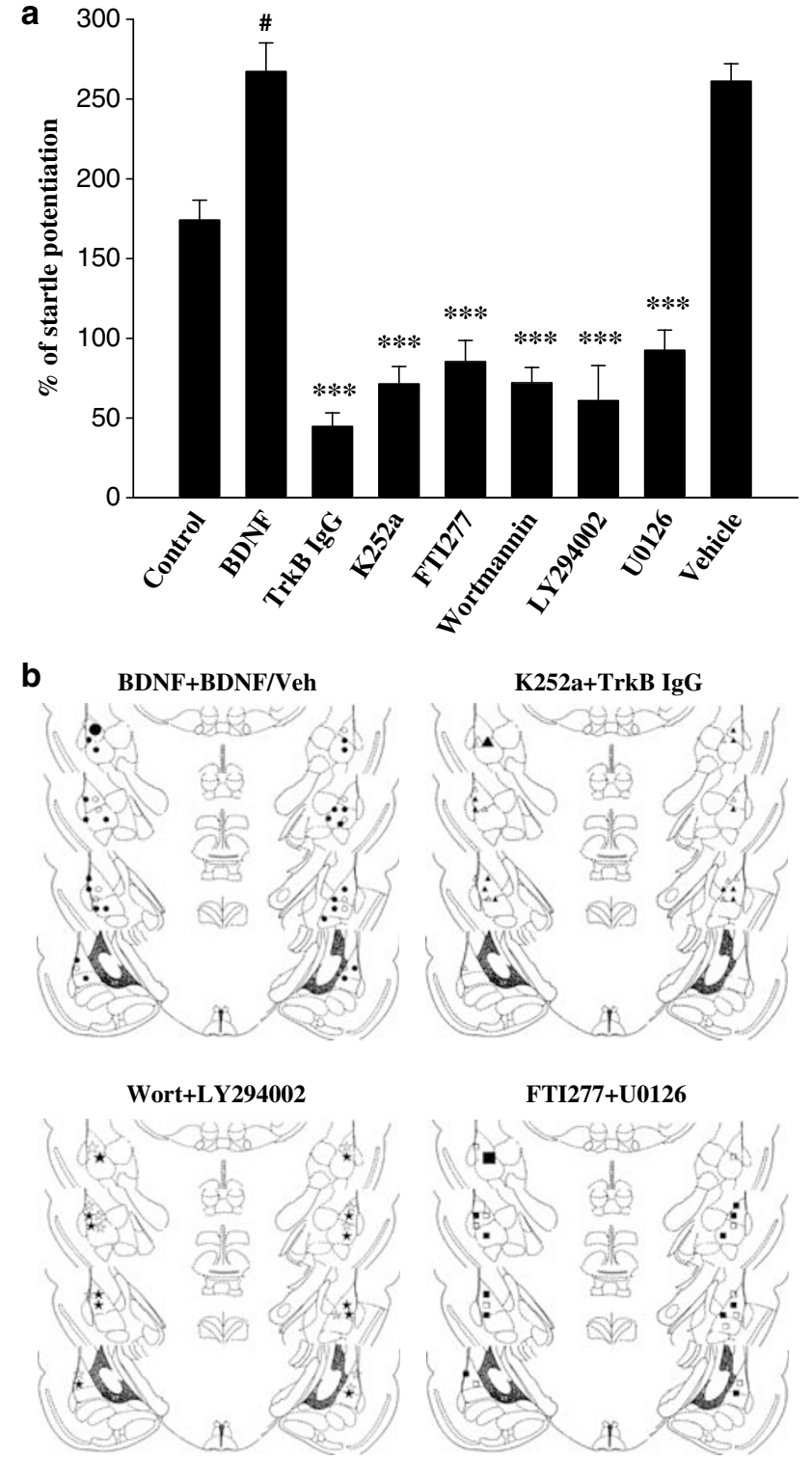

Figure 3 Effects of intra-amygdala administration of drugs on BDNFinduced enhancement of fear memory. (a) BDNF $(0.2 \mu \mathrm{g} / \mu \mathrm{l}, 1.5 \mu \mathrm{l}$ per side) was microinjected bilaterally into the LA or BLA 30 min before training. $\mathrm{K} 252 \mathrm{a}(35.7 \mu \mathrm{M}$ in 50\% DMSO, I.5 $\mu$ per side), TrkB IgG (I.3 $\mu \mathrm{g}$ in I $\mu \mathrm{l} \mathrm{PBS}$ solution, I. $5 \mu$ l per side), wortmannin ( $5 \mu \mathrm{g} / \mu \mathrm{l}$ in $50 \%$ DMSO, I $\mu$ l per side), LY294002 (30 $\mu \mathrm{g} / \mu \mathrm{l}$ in 50\% DMSO, I $\mu \mathrm{l}$ per side) or $\cup 0 \mathrm{I} 26(\mathrm{I} \mu \mathrm{g} / \mu \mathrm{l}$ in $50 \%$ DMSO, I $\mu$ l per side) was coadministered with BDNF. FTI277 (2.5 mM in $50 \%$ DMSO, I. $5 \mu \mathrm{l}$ per side) was given $24 \mathrm{~h}$ before training. ${ }^{*} p<0.00 \mathrm{I}$ vs control, $* * * * 0.00$ I, $* * p<0.0$ I vs BDNF. (b) Cannula tip placements from rats giving $\mathrm{BDNF}(\mathbf{O})$ and $\mathrm{BDNF}$ plus K252a $(\mathrm{O})$, FTI277 $(\star)$, wortmannin $(\boldsymbol{\Lambda}), \operatorname{LY} 294002(\Delta)$, U0I26 (is) and vehicle $(\boldsymbol{\square})$ in experiments (a).

BLA were immunoprecipitated with Shc (H-108) antibody and immunoblotted with $\operatorname{TrkB}$ antibody at various time points after fear conditioning. As shown in Figure $4 \mathrm{a}$, fear training caused a transient increase in TrkB which bound to Shc $\left(\mathrm{F}_{(3,16)}=44.78, p<0.001\right)$. A set of parallel immunoblots with an antibody that detects TrkB were performed to show that the total levels of TrkB were not altered. Secondly, protein extracts were immunoprecipitated with Shc (H-108) antibody and immunoblotted with Ras. Fear training 
BDNF enhancement of fear-potentiated startle, we bilater-

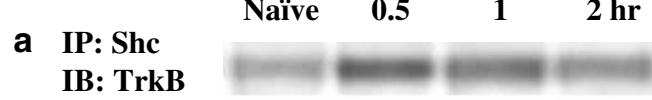

TrkB

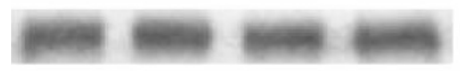

b IP: Shc

IB: Ras

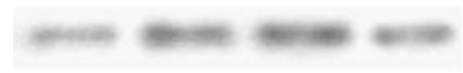

She

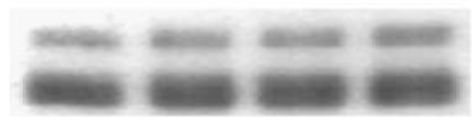

C

GTP-Ras

Ras

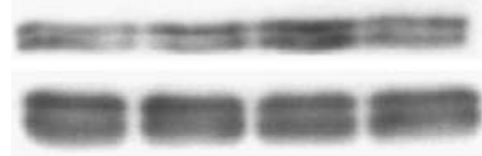

d

P-MAPK

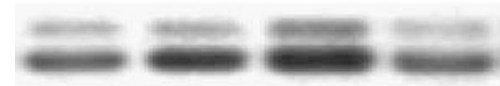

MAPK

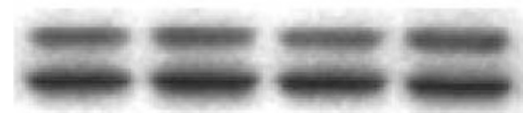

Figure 4 Fear conditioning results in the interaction between TrkB and Shc. (a) At 0.5, I, and $2 \mathrm{~h}$ after fear conditioning, protein extracts from LA and BLA were immunoprecipitated with Shc antibody and immunoblotted with TrkB antibody. (b) Protein extracts were immunoprecipitated with Shc antibody and immunoblotted with Ras. (c) Active Ras was determined by a pulldown assay as described in Materials and methods. (d) Representative blots of phosphorylated p42 and p44 and total 42 and 44 immunoreactivities from the LA and BLA

resulted in a transient increase in Ras which bound to Shc $\left(\mathrm{F}_{(3,16)}=5.82, p<0.01\right)$ (Figure $\left.4 \mathrm{~b}\right)$. As the expression of $\mathrm{N}$ Shc is restricted to the nervous system and spleen, a parallel protein extract was also immunoblotted with $\mathrm{N}$-Shc and the result revealed that the total $\mathrm{N}-\mathrm{Shc}$ was unchanged.

Ras is a small guanine nucleotide-binding protein and its signaling pathway is important for long-term memory formation in the amygdala (Brambilla et al, 1997). In the hippocampus, Ras transduces BDNF signal to the downstream effectors, including MAPK and PI-3 kinase (Iida et al, 2001). We investigated the function of Ras in fear conditioning by a pulldown assay using Ras-binding domain of Raf fused to GST. This fusion protein-agarose conjugate will specifically bind to and precipitate Ras-GTP from cell lysates. Precipitation reactions were followed by Western blotting with a Ras antibody (de Rooij and Bos, 1997; Iida et al, 2001). As shown in Figure 4c, $1 \mathrm{~h}$ after fear training the level of active Ras was significantly greater than unpaired controls $\left(\mathrm{F}_{(3,12)}=24.79, p<0.001\right)$. To examine signal cascades downstream of TrkB, we assessed the levels of MAPK phosphorylation and found that both MAPK isoforms were activated $1 \mathrm{~h}$ after fear conditioning ( $\mathrm{p} 42$ : $146.3 \pm 5.0 \%$; p $44: 154.8 \pm 5.5 \%$ of naïve control, $n=6$, $p<0.01$ ) (Figure $4 \mathrm{~d}$ ).

Ras is lipid-modified by a farnesyl group and that farnesylation is required for Ras transforming activity. To determine the involvement of Ras in fear conditioning and ally administered a selective farnesyltransferase inhibitor FTI277 (Lerner et al, 1995; Sebti and Hamilton, 1997; Suzuki et al, 1998) into the amygdala $(2.5 \mathrm{mM}$ in $50 \%$ DMSO, $1.5 \mu \mathrm{l}$ per side) $24 \mathrm{~h}$ before fear conditioning. Figure 2a shows that farnesyl transferase inhibitor by its own inhibited the startle amplitude $(73.7 \pm 14.1 \%, n=6, p<0.001)$, and blocked the action of BDNF $\left(t_{(16)}=6.6, p<0.001\right)$ (Figure 3a).

We performed behavioral assessment to determine whether the enhancement of fear-potentiated startle by BDNF was mediated by activation of MAPK. In the first set of experiments, rats were divided into four groups: paired rats that received MEK (MAPK kinase) inhibitor U0126 $(1 \mu \mathrm{g} / \mu \mathrm{l}$ in $50 \%$ DMSO, $1 \mu \mathrm{l}$ per side $)$ or vehicle, and unpaired rats that were given U0126 or vehicle. A two-way ANOVA revealed a main effect of group (paired $v s$ unpaired, $\left.\mathrm{F}_{(1,20)}=59.25, p<0.001\right)$, drug treatment (U0126 vs vehicle, $\left.\mathrm{F}_{(1,20)}=7.01, p<0.02\right)$, and interaction $\left(\mathrm{F}_{(1,20)}=\right.$ 17.57, $p<0.001)$. Post hoc comparisons indicated that startle potentiation in paired-U0126 rats was significantly less than paired-Veh rats $(p<0.001$, Figure 2a), confirming a requirement of MAPK activation for fear conditioning. Furthermore, startle reflex in unpaired-U0126 rats was comparable with those unpaired rats receiving vehicle (unpaired-Veh) $(p=0.17)$, ruling out the nonspecific action of U0126 on fear-potentiated startle.

Next, rats were administered U0126 or vehicle $20-25 \mathrm{~min}$ before BDNF or vehicle. A two-way ANOVA revealed a main effect of drug treatment (U0126 vs vehicle, $\mathrm{F}_{(1,20)}=31.14$, $p<0.001)$ without any effect of group (BDNF $v s$ vehicle, $\left.\mathrm{F}_{(1,20)}=3.76, p>0.05\right)$. The absence of the effect of group indicated that MEK inhibitor blocked fear-potentiated startle (Figure 2a) and the enhancement effect of BDNF (Figure 3a). However, the drug treatment $\times$ group interaction was significant $\left(\mathrm{F}_{(1,20)}=5.15, p<0.05\right)$.

We examined whether the pretesting injection of U0126 affected fear memory. The results showed that there was no difference in the startle amplitude between U0126 $(181.1 \pm 10.1, n=6)$ and vehicle $(178.7 \pm 11.5, n=6)$ groups $\left(t_{(10)}=0.16, p=0.88\right)$.

To determine whether the enhancement of fear-potentiated startle by BDNF was mediated by activation of PI-3 kinase, rats were divided into four groups: paired rats that received wortmannin $(5 \mu \mathrm{g} / \mu \mathrm{l}$ in $50 \%$ DMSO, $1 \mu \mathrm{l}$ per side) or vehicle and unpaired rats that were given wortmannin or vehicle. A two-way ANOVA revealed a main effect of group $\left(\mathrm{F}_{(1,20)}=44.26, p<0.001\right)$, drug treatment $\left(\mathrm{F}_{(1,20)}=14.66\right.$, $p<0.005)$, and interaction $\left(\mathrm{F}_{(1,20)}=17.39, p<0.001\right)$. Post hoc comparisons indicated that startle potentiation in paired-wortmannin rats was significantly less than pairedVeh rats $(p<0.001$, Figure $2 a)$, confirming a requirement of PI-3 kinase activation for fear conditioning. Furthermore, startle reflex in unpaired-wortmannin rats was comparable with those unpaired rats receiving vehicle (unpaired-Veh) $(p=0.10)$, ruling out the nonspecific action of wortmannin on fear-potentiated startle.

Rats were given wortmannin or vehicle 20-25 min before BDNF or vehicle. A two-way ANOVA revealed a main effect of drug treatment $\left(\mathrm{F}_{(1,20)}=43.21, p<0.001\right)$ without any effect of group $\left(\mathrm{F}_{(1,20)}=3.98, p>0.05\right)$. The absence of effect of group indicated that PI-3 kinase inhibitor blocked fearpotentiated startle (Figure 2a) and the enhancement effect 
of BDNF (Figure 3a). However, the drug treatment $\times$ group interaction was significant $\left(\mathrm{F}_{(1,20)}=4.95, p<0.05\right)$.

Similar results were obtained with another PI-3 kinase inhibitor, LY294002 (30 $\mu \mathrm{g} / \mu \mathrm{l}$ in 50\% DMSO, $1 \mu \mathrm{l}$ per side). Figure 2a shows that LY294002 produced a marked depression of startle $(74.3 \pm 16.4 \%, n=6, p<0.001)$ and blocked the action of BDNF $(p<0.001)$ (Figure 3a).

\section{Amygdala Slice Preparation}

We explored the possible signal pathway underlying BDNF enhancement of startle reflex. Rats were decapitated and amygdala slices were made. Slices were incubated with BDNF $(100 \mathrm{ng} / \mathrm{ml})$ for $15 \mathrm{~min}$ and homogenates from LA and BLA were prepared. Active GTP-bound Ras was measured by a pulldown assay. Figure 5 shows that BDNF treatment significantly increased the level of active Ras and the increase was abolished when slices were pretreated with $\mathrm{K} 252 \mathrm{a}(300 \mathrm{nM}) 30 \mathrm{~min}$ before the application of BDNF.

We next determined whether BDNF induced MAPK activation. Amygdala slices were incubated with BDNF $(100 \mathrm{ng} / \mathrm{ml})$ for $15 \mathrm{~min}$ and then BDNF was washed out. At various periods after the washout of BDNF, MAPK phosphorylation was analyzed. Figure 6a shows that BDNF treatment increased the levels of P-42 and P-44 MAPK (p42: $\left.\mathrm{F}_{(4,43)}=40.99, p<0.0001 ; \mathrm{p} 44: \mathrm{F}_{(4,43)}=25.20, p<0.0001\right)$ in the amygdala slices. No change was observed when blotted membrane was reprobed with an antibody that recognizes MAPK independently of its phosphorylation state, indicating that the observed changes in activated MAPK were not the result of unequal protein loading. Figure $6 \mathrm{~b}$ shows that BDNF caused p42 and p44 MAPK phosphorylation to $156.3 \pm 8.0$ and $164.8 \pm 8.5 \%$ of control $(n=6)$. Pretreatment of amygdala slices with K252a (300 nM) $30 \mathrm{~min}$ before BDNF stimulation completely blocked BDNF-induced activation of MAPK (p42: $100.6 \pm 1.4 \%$ of control, $n=6$; p44: $102.3 \pm 2.4 \%$ of control, $n=6$ ), indicating the mediation of BDNF effect by TrkB receptors. As a positive control,

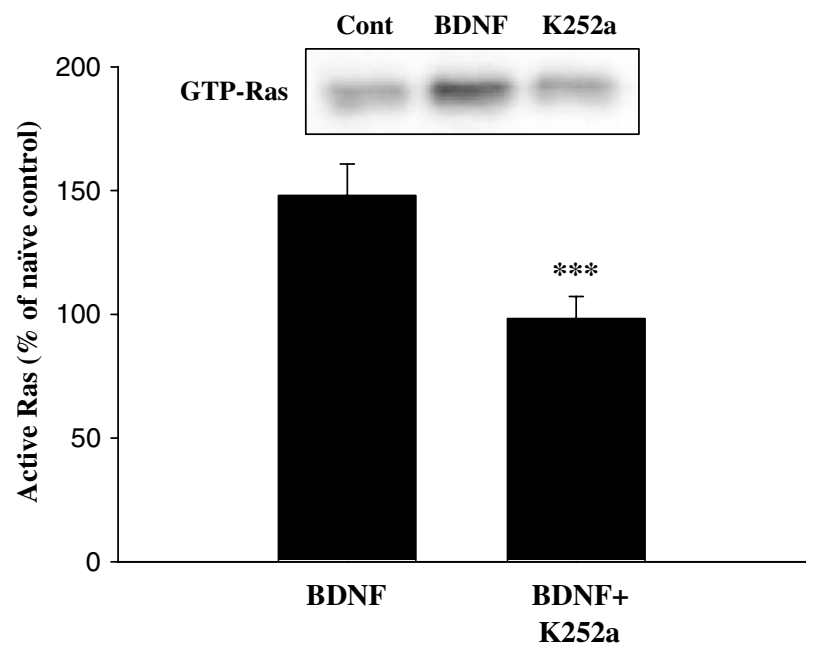

Figure 5 BDNF treatment increases the levels of active Ras. Amygdala slices were incubated with BDNF $(100 \mathrm{ng} / \mathrm{ml})$ for 15 min and active Ras was determined by a pulldown assay. BDNF-induced increase in active Ras was abolished when slices were pretreated with K252a (300 nM).
MEK inhibitors U0126 $(10 \mu \mathrm{M})$ or PD98059 $(50 \mu \mathrm{M})$ reduced the phosphorylation levels of p42 to $55.5 \pm 5.9 \%(n=6)$ and $59.8 \pm 1.5 \%(n=6)$ of control, respectively, and $\mathrm{p} 44$ to
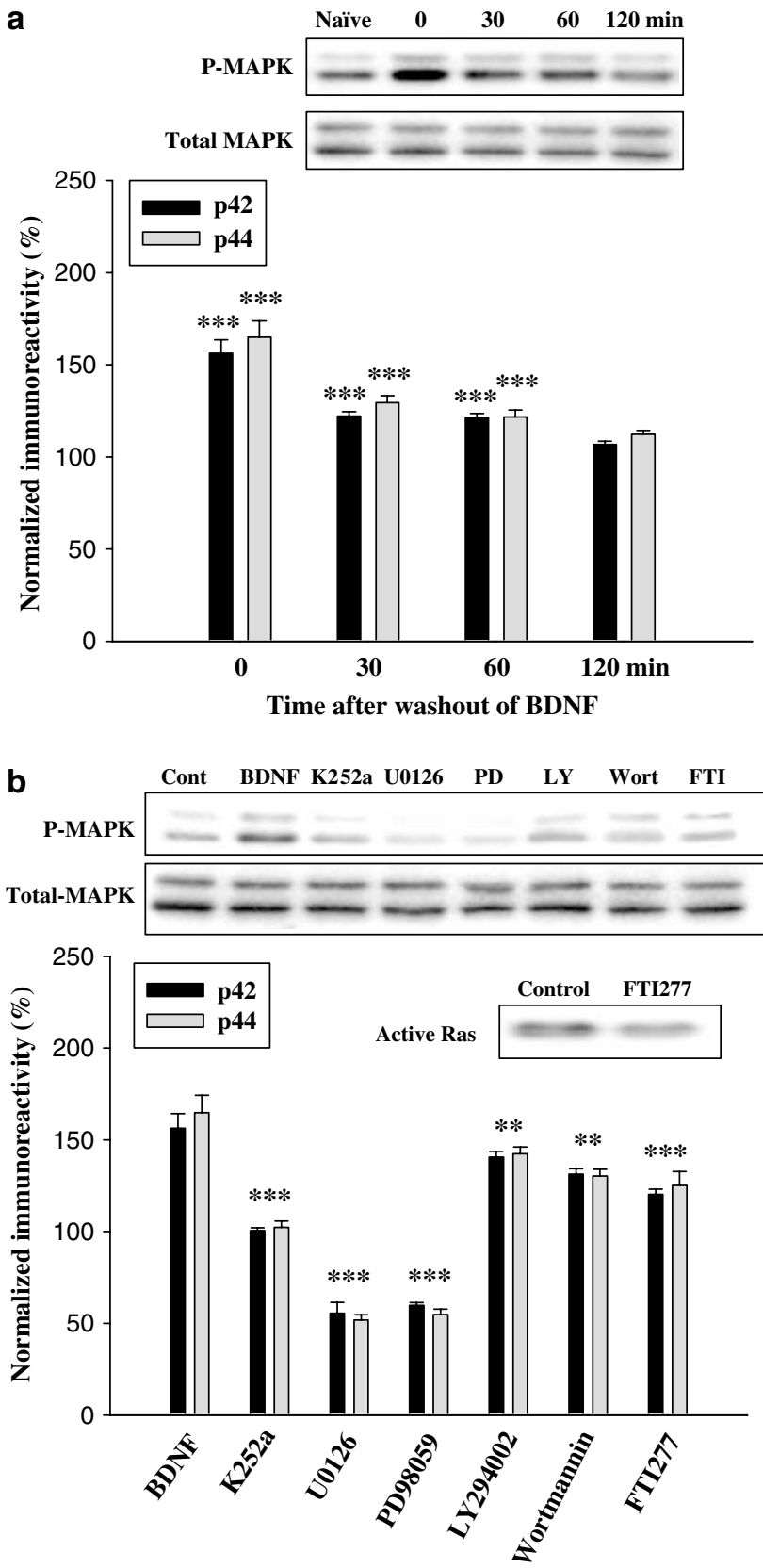

Figure 6 BDNF increases the levels of MAPK phosphorylation in the amygdala. Figures show representative Western blots and densitometric analysis of MAPK phosphorylation induced by BDNF. Amygdala slices were incubated with BDNF $(100 \mathrm{ng} / \mathrm{ml})$ for $15 \mathrm{~min}$ and then BDNF was washed out. (a) Protein extracts were analyzed at various periods after washout of BDNF by Western blotting with $\alpha$-dual-P-ERK and reprobed with $\alpha$-ERK antibodies. ${ }^{*} * * * 0.00$ I vs control slices without treatment with BDNF. (b) Effects of drugs on BDNF-induced MAPK phosphorylation. K252a

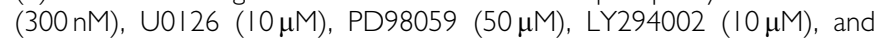
wortmannin $(100 \mathrm{nM})$ were added to the slice preparation $30 \mathrm{~min}$ before the application of BDNF, whereas FTI277 (2.5 mM in 50\% DMSO, I.5 $\mu \mathrm{M}$ per side) was infused into the amygdala $24 \mathrm{~h}$ before the preparation of slices. **** $p<0.00$ I vs BDNF. The inset shows a positive control demonstrating that active Ras was significantly reduced in slices from FTI277 pretreated animals. 
$51.8 \pm 2.9 \%(n=6)$ and $54.8 \pm 2.9 \%(n=6)$ of control, respectively.

We examined the role of PI-3 kinase in BDNF-induced activation of MAPK. Application of wortmannin (100 nM) 30 min before BDNF stimulation inhibited BDNF-induced p42 and p44 MAPK activation from $156.3 \pm 8.0$ and $164.8 \pm$ $8.5 \%$ to $131.3 \pm 3.0 \%(n=6, p<0.01)$ and $130.2 \pm 3.8 \%$ $(n=6, p<0.01)$ of control, respectively. In the same vein, LY294002 $(10 \mu \mathrm{M})$ reduced BDNF-induced $\mathrm{p} 42$ and p44 MAPK activation to $140.6 \pm 3.0 \% \quad(n=6, p<0.01)$ and $142.5 \pm 3.7 \%(n=6, p<0.01)$ of control, respectively. We also investigated whether farnesyltransferase inhibitor affected BDNF-induced MAPK activation. Rats were

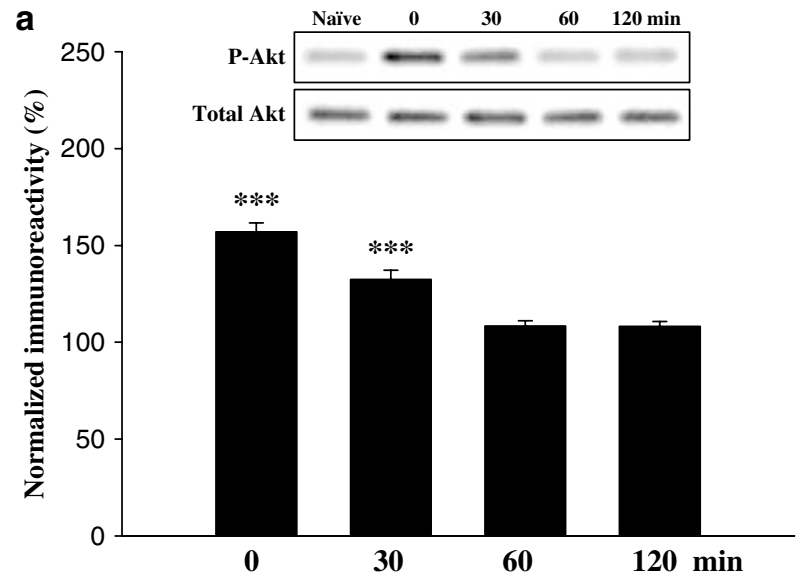

Time after washout of BDNF

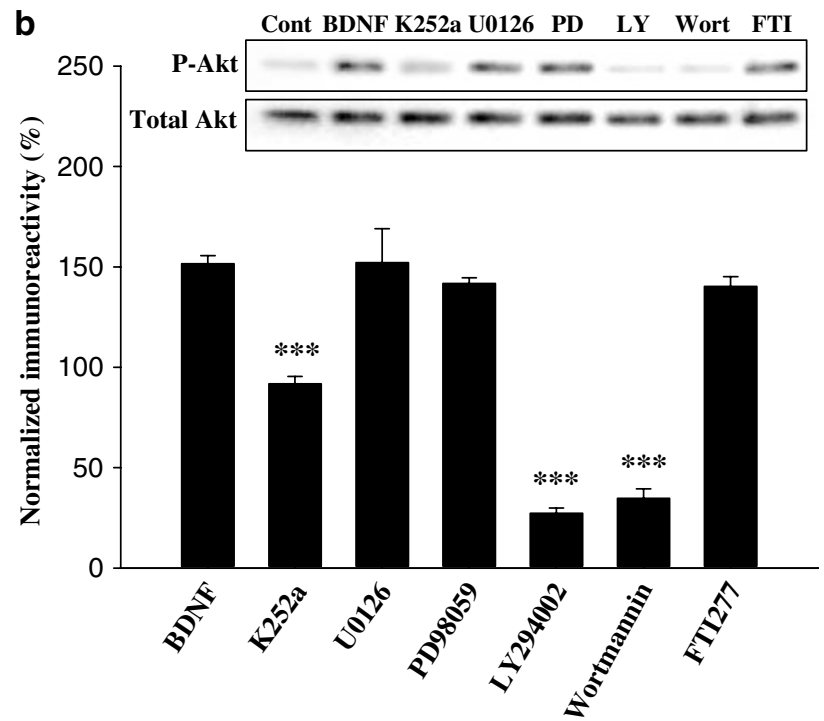

Figure 7 BDNF increases the levels of Akt phosphorylation in the amygdala. Amygdala slices were incubated with BDNF $(100 \mathrm{ng} / \mathrm{ml})$ for 15 min and then BDNF was washed out. (a) Protein extracts were analyzed at various periods after washout of BDNF by Western blotting with $\mathrm{p}$-Akt and reprobed with Akt antibodies. $* * * * 00.00$ I vs control slices without treatment with BDNF. (b) Effects of drugs on BDNF-induced Akt

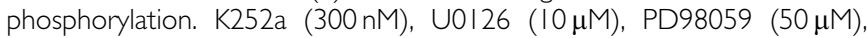
LY294002 $(10 \mu M)$, and wortmannin $(100 \mathrm{nM})$ were added to the slice preparation $30 \mathrm{~min}$ before the application of BDNF, whereas FTI277 ( $2.5 \mathrm{mM}$ in $50 \%$ DMSO, $1.5 \mu \mathrm{M}$ per side) was infused into the amygdala $24 \mathrm{~h}$ before the preparation of slices. $* * * * 00.001$ vs BDNF. pretreated with FTI277 $(2.5 \mathrm{mM}$ in 50\% DMSO, $1.5 \mu \mathrm{l}$ per side), and, $24 \mathrm{~h}$ later, amygdala slices were prepared. Active Ras was decreased by this treatment $(67.9 \pm 2.6 \%$ of control, $n=5)$. Furthermore, BDNF-induced MAPK activation was partially inhibited in slices from FTI277-pretreated rats (p42: $120.2 \pm 2.8 \%$ of control, $n=6 ; \mathrm{p} 44: 125.0 \pm 7.7 \%$ of control, $n=6, p<0.01$ ) (Figure 6b).

Similar experiments were performed to determine the activation of Akt. As shown in Figure 7a, BDNF treatment increased the level of Akt phosphorylation $\left(\mathrm{F}_{(4,51)}=30.66\right.$, $p<0.0001)$. Figure $7 \mathrm{~b}$ shows that pretreatment of slices with K252a (300 nM) 30 min before BDNF stimulation blocked BDNF-induced Akt phosphorylation $(91.8 \pm 3.7 \%$ of control, $n=5, p<0.001 v s$ BDNF alone). By contrast, U0126 (10 $\mu \mathrm{M})$ or PD98059 $(50 \mu \mathrm{M})$ did not affect BDNF-induced Akt phosphorylation (U0126: $152.2 \pm 16.8 \%$ of control, $n=5$; PD98059: $141.7 \pm 2.9 \%$ of control, $n=5, p>0.05$ in both cases), arguing against an involvement of MEK in the activation of PI-3 kinase. As a positive control, LY294002 $(10 \mu \mathrm{M})$ or wortmannin $(100 \mathrm{nM})$ reduced the phosphorylation levels of Akt to below the baseline $(27.3 \pm 2.6 \%$ of control, $n=5$, and $34.7 .1 \pm 4.8 \%$ of control, $n=5$, respectively). Furthermore, Ras inhibitor FTI277 when administered into the amygdala $(2.5 \mathrm{mM}$ in $50 \%$ DMSO, $1.5 \mu \mathrm{M}$ per side) $24 \mathrm{~h}$ before slice preparation did not influence the effect of BDNF on PI-3 kinase activation (140.3 $\pm 5.4 \%$, $n=5, p=0.1)$.

\section{DISCUSSION}

In this report, we show that (1) fear conditioning caused an increase in BDNF protein and activation of $\operatorname{TrkB}$ receptors in the amygdala; (2) bilateral administration of BDNF to the amygdala enhanced fear-potentiated startle and this effect was blocked by a TrkB ligand scavenger TrkB IgG and Trkspecific tyrosine kinase inhibitor; (3) fear conditioning resulted in an association of $S h c$ and TrkB receptor, leading to the activation of Ras, and farnesyltransferase inhibitor significantly reduced fear-potentiated startle; (4) treatment of amygdala slices with BDNF increased phosphorylation of MAPK and MEK inhibitors blocked BDNF-induced MAPK phosphorylation and enhancement of startle reflex; (5) treatment of amygdala slices with BDNF increased Akt phosphorylation and PI-3 kinase inhibitors blocked BDNFinduced Akt phosphorylation and enhancement of startle reflex, and (6) activation of MAPK by BDNF was partially inhibited by wortmannin or LY 294002, suggesting that PI-3 kinase is an early intermediate in the BDNF-activated MAPK signaling pathway. Taken together, these results demonstrate a functional role of BDNF in fear learning and delineate signaling pathways coupled to $\operatorname{TrkB}$ receptor activation.

\section{BDNF and Fear Conditioning}

Animals that received conditioning trials of light paired with footshock showed a temporary increase in BDNF protein levels that peaked at $1 \mathrm{~h}$ and returned to control level within $4 \mathrm{~h}$ after training in the amygdala. Similarly, TrkB phosphorylation peaked at $1 \mathrm{~h}$ after fear conditioning. Conversely, BDNF expression and TrkB phosphorylation 
were not observed in unpaired controls, suggesting that the increase depends on the learned association between light and footshock. It has been shown recently that BDNF in the amygdala is involved in odor and light conditioning (Rattiner et al, 2004). In that study, a lentiviral vector expressing dominant-negative TrkB isoform was used, which specifically blocked memory acquisition without disrupting baseline startle or expression of fear. Our data revealed that acquisition of fear memory was impaired by TrkB ligand scavenger and Trk-specific tyrosine kinase inhibitor. In addition, bilateral administration of BDNF to the amygdala enhanced fear-potentiated startle, and this effect was blocked in K252a-treated animals such that there was no difference in startle reflex between K252a- and $\mathrm{BDNF} / \mathrm{K} 252 \mathrm{a}$-treated rats. These data suggest a requirement of BDNF expression and activation of TrkB receptor in the amygdala for fear learning.

A pharmacological inhibitor of TrkB, notably K252a, has been widely used to study TrkB function. However, the interpretation of experiments should be cautious due to limited drug specificity. We therefore also used a neutralizing antibody. Future studies may apply recently developed Trk mutant mice which allow for pharmacological control of Trk signaling (Chen et al, 2005) to address neurotrophin function in the amygdala.

\section{Signal Cascades}

Many of the signaling cascades involved in the induction of LTP and formation of long-term memory may converge on and activate MAPK (Sweatt, 2001). For example, emotional memory and LTP in the BLA were impaired in mice that lack the neuronal-specific exchange Ras-guanine nucleotide-releasing factor (Ras-GRF) (Brambilla et al, 1997). RasGRF is a potent activator of MAPK signaling, suggesting a role for Ras/MAPK cascade. Indeed, it has been shown that pharmacological inhibition of MAPK interfered with fear memory and protein synthesis-dependent late LTP in the amygdala (Schafe et al, 2000; Huang et al, 2000). Here, we show that fear training elicited the association of Shc and TrkB receptor, Shc and Ras, the increase in the active Ras, and the activation of MAPK. BDNF enhanced startle reflex and our biochemical analysis showed that MAPK was activated following treatment with BDNF. BDNF-induced phosphorylation of MAPK was completely blocked by $\mathrm{K} 252 \mathrm{a}$, confirming the mediation via tyrosine kinase receptor TrkB. Farnesyltransferase inhibitor partially prevented the effect of BDNF on MAPK phosphorylation. Thus, BDNF binding to TrkB receptors leads to phosphorylation of tyrosine residues in the intracellular domain of the TrkB receptors, recruiting the docking protein Shc. Shc, which in turn recruits Grb2/SOS complex, activates Raf, MEK, and MAPK. BDNF-induced interaction between TrkB receptor and Shc also stimulates PI-3 kinase. Interestingly, BDNFinduced Akt phosphorylation was not affected by MEK inhibitors, whereas PI-3 kinase inhibitors attenuated BDNFinduced MAPK phosphorylation. These results indicate that PI-3 kinase may be an upstream regulator of MAPK and BDNF induces MAPK activation via several overlapping mechanisms that may be Akt-dependent and -independent. Taken together, our results suggest that fear conditioning stimulates the expression of BDNF, which promotes and maintains neural plasticity. BDNF enhances fear-potentiated startle likely through MAPK and PI-3 kinase pathways. BDNF induced MAPK phosphorylation in the amygdala, which is mediated via TrkB and the Shc-binding site. Shc binding to TrkB leads to activation of Ras, Raf, MEK, and MAPK. In addition, BDNF could induce phosphorylation of MAPK via activation of PI-3 kinase.

Recently, Monteggia et al have generated an inducible knockout system in which BDNF can be deleted selectively in the brain of adult mice. The hippocampus-dependent context freezing was impaired in these mice, whereas amygdala-dependent cue freezing was normal (Monteggia et al, 2004). Although the two forms of memory index, cue freezing and fear-potentiated startle, are dependent on the amygdala, they may be affected by different neural networks and signal cascades. It would be of interest for the future studies to determine if conditional BDNF knockout animals exhibit impairment in fear-potentiated startle. In conclusion, the results of this study not only demonstrate the requirement of BDNF and activation of its receptor TrkB for fear learning, but also characterize downstream signal pathways, which involves recruitment of docking protein Shc, leading to activation of MAPK and PI-3 kinase. Thus, BDNF and its downstream signal pathways may become an avenue of therapeutic intervention for the treatment of post-traumatic stress disorders.

\section{ACKNOWLEDGEMENTS}

This study was supported by the National Health Research Institutes (NHRI-EX92-9202NI) and National Science Council (NSC94-2752-B-006-001-PAE).

\section{REFERENCES}

Binder DK, Routbort MJ, McNamara JO (1999). Immunohistochemical evidence of seizure-induced activation of Trk receptors in the mossy fiber pathway of adult rat hippocampus. J Neurosci 19: $4616-4626$.

Brambilla R, Gnesutta N, Minichiello L, White G, Roylance AJ, Herron CE et al (1997). A role for the Ras signalling pathway in synaptic transmission and long-term memory. Nature 390: 281-286.

Chen G, Kolbeck R, Barde YA, Bonhoeffer T, Kossel A (1999). Relative contribution of endogenous neurotrophins in hippocampal long-term potentiation. J Neurosci 19: 7983-7990.

Chen X, Ye H, Kuruvilla R, Ramanan N, Scangos KW, Zhang C et al (2005). A chemical-genetic approach to studying neurotrophin signaling. Neuron 46: 13-21.

de Rooij J, Bos JL (1997). Minimal Ras-binding domain of Raf1 can be used as an activation-specific probe for Ras. Oncogene 14: 623-625.

Figurov A, Pozzo-Miller LD, Olafsson P, Wang T, Lu B (1996). Regulation of synaptic responses to high-frequency stimulation and LTP by neurotrophins in the hippocampus. Nature 381: 706-709.

Grimm JW, Lu L, Hayashi T, Hope BT, Su TP, Shaham Y (2003). Time-dependent increases in brain-derived neurotrophic factor protein levels within the mesolimbic dopamine system after withdrawal from cocaine: implications for incubation of cocaine craving. J Neurosci 23: 742-747.

Hall J, Thomas KL, Everitt BJ (2000). Rapid and selective induction of BDNF expression in the hippocampus during contextual learning. Nat Neurosci 3: 533-535. 
Hetman M, Kanning K, Cavanaugh JE, Xia Z (1999). Neuroprotection by brain-derived neurotrophic factor is mediated by extracellular signal-regulated kinase and phosphatidyl-3-kinase. J Biol Chem 274: 22569-22580.

Huang YY, Martin KC, Kandel ER (2000). Both protein kinase A and mitogen-activated protein kinase are required in the amygdala for the macromolecular synthesis-dependent late phase of long-term potentiation. J Neurosci 20: 6317-6325.

Iida N, Namikawa K, Kiyama H, Ueno H, Nakamura S, Hattori S (2001). Requirement of Ras for the activation of mitogenactivated protein kinase by calcium influx, cAMP, and neurotrophin in hippocampal neurons. J Neurosci 21: 6459-6466.

Johan DR, Johannes LB (1997). Minimal Ras-binding domain of Rafl can be used as an activation-specific probe for Ras. Oncogene 14: 623-625.

Kang H, Schuman EM (1995). Long-lasting neurotrophin-induced enhancement of synaptic transmission in the adult hippocampus. Science 267: 1658-1662.

Kang H, Welcher AA, Shelton D, Schuman EM (1997). Neurotrophins and time: differet roles for TrkB signaling in hippocampal long-term potentiation. Neuron 19: 653-664.

Kaplan DR, Miller FD (2000). Neurotrophin signal transduction in the nervous system. Curr Opin Neurobiol 10: 381-391.

Korte M, Carroll P, Wolf E, Brem G, Thoenen H, Bonhoeffer T (1995). Hippocampal long-term potentiation is impaired in mice lacking brain-derived neurotrophic factor. Proc Natl Acad Sci USA 92: 8856-8860.

Lee JL, Everitt BJ, Thomas KL (2004). Independent cellular processes for hippocampal memory consolidation and reconsolidation. Science 304: 839-843.

Lerner EC, Qian Y, Blaskovich MA, Fossum RD, Vogt A, Sun J et al (1995). Ras CAAX peitidomimetic FTI-277 selectively blocks oncogenic Ras signaling by inducing cytoplasmic accumulation of inactive Ras-Raf complexes. J Biol Chem 270: 26802-26806.

Lin CH, Yeh HW, Lin CH, Lu KT, Leu TH, Chang WC et al (2001). A role for the PI-3 kinase signaling pathway in fear conditioning and synaptic plasticity in the amygdala. Neuron 31: 841-851.

Lu L, Dempsey J, Liu SY, Bossert JM, Shaham Y (2004). A single infusion of brain-derived neurotrophic factor into the ventral tegmental area induces long-lasting potentiation of cocaine seeking after withdrawal. J Neurosci 24: 1604-1611.

Ma YL, Wang HL, Wu HC, Wei CL, Lee HH (1998). Brain-derived neurotrophic factor antisense oligonucleotide impairs memory retention and inhibits long-term potentiation in rats. Neuroscience 82: 957-967.

McAllister AK, Lo DC, Katz LC (1995). Neurotrophins regulate dendritic growth in developing visual cortex. Neuron 15: 791-803.

Messaoudi E, Ying SW, Kanhema T, Croll SD, Bramham CR (2002). Brain-derived neurotrophic factor triggers transcription-dependent, late phase long-term potentiation in vivo. J Neurosci 22: 7453-7461.

Mizuno M, Yamada K, Olariu A, Nawa H, Nabeshima T (2000). Involvement of brain-derived neurotrophic factor in spatial memory formation and maintenance in a radial arm maze test in rats. J Neurosci 20: 7116-7121.

Mizuno M, Yamada K, He J, Nakajima A, Nabeshima T (2003). Involvement of BDNF receptor TrkB in spatial memory formation. Learn Memory 10: 108-115.

Monteggia LM, Barrot M, Powell CM, Berton O, Galanis V, Gemelli $\mathrm{T}$ et al (2004). Essential role of brain-derived neurotrophic factor in adult hippocampal function. Proc Natl Acad Sci USA 101: 10827-10832.

Patterson SL, Abel T, Deuel TA, Martin KC, Rose JC, Kandel ER (1996). Recombinant BDNF rescues deficits in basal synaptic transmission and hippocampal LTP in BDNF knockout mice. Neuron 16: 1137-1145.

Patterson SL, Pittenger C, Morozov A, Martin KC, Scanlin H, Drake $\mathrm{C}$ et al (2001). Some forms of cAMP-mediated long-lasting potentiation are associated with release of BDNF and nuclear translocation of phospho-MAP kinase. Neuron 32: 123-140.

Pang PT, Teng HK, Zaitsev E, Woo NT, Sakata K, Zhen S et al (2004). Cleavage of proBDNF by tPA/plasmin is essential for long-term hippocampal plasticity. Science 306: 487-491.

Paxinos G, Watson C (1986). The Rat Brain in Stereotaxic Coordinates. Academic Press: New York, 119pp.

Poo MM (2001). Neurotrophins as synaptic modulators. Nat Rev Neurosci 2: 24-32.

Rattiner LM, Davis M, French CT, Ressler KJ (2004). Brain-derived neurotrophic factor and tyrosine kinase receptor B involvement in amygdala-dependent fear conditioning. $J$ Neurosci 24: 4796-4806.

Ravichandran KS (2001). Signaling via Shc family adapter proteins. Oncogene 20: 6322-6330.

Schafe GE, Atkins CM, Swank MW, Bauer EP, Sweatt JD, LeDoux JE (2000). Activation of ERK/MAP kinase in the amygdala is required for memory consolidation of pavlovian fear conditioning. J Neurosci 20: 8177-8187.

Schuman EM (1999). Neurotrophin regulation of synaptic transmission. Curr Opin Neurobiol 9: 105-109.

Sebti SM, Hamilton AD (1997). Inhibition of Ras prenylation: a novel approach to cancer chemotherapy. Pharmacol Ther 74: 103-114.

Shelton DL, Sutherland J, Gripp J, Camerato T, Armkanini MP, Philips HS et al (1995). Human Trks: molecular cloning, tissue distribution, and expression of extracellular domain immunoadhesins. J Neurosci 15: 477-491.

Suzuki N, Urano J, Tamanoi F (1998). Tarnesyltransferase inhibitors induce cytochrome $C$ release and caspase 3 activation preferentially in transformed cells. Proc Natl Acad Sci USA 95: $15356-15361$

Sweatt JD (2001). The neuronal MAP kinase cascade: a biochemical signal integration system subserving synaptic plasticity and memory. J Neurochem 76: 1-10.

Tokuyama W, Okuno H, Hashimoto T, Xin Li Y, Miyashita Y (2000). BDNF upregulation during declarative memory formation in monkey inferior temporal cortex. Nat Neurosci 3: $1134-1142$.

Tyler WJ, Alonso M, Bramham CR, Pozzo-Miller LD (2002). From acquisition to consolidation: on the role of brain-derived neurotrophic factor signaling in hippocampal-dependent learning. Learn Memory 9: 224-237.

Yamada K, Mizuno M, Nabeshima T (2002). Role for brain-derived neurotrophic factor in learning and memory. Life Sci 70: 735-744.

Ying SW, Futter M, Rosenblum K, Webber MJ, Hunt SP, Bliss TVP et al (2002). Brain-derived neurotrophic factor induces longterm potentiation in intact adult hippocampus: requirement for ERK activation coupled to CREB and upregulation of Arc synthesis. J Neurosci 22: 1532-1540.

Zhang X, Poo MM (2002). Localized synaptic potentiation by BDNF requires local protein synthesis in the developing axon. Neuron 36: 675-688. 